\title{
検査時期による眼振所見の変化
}

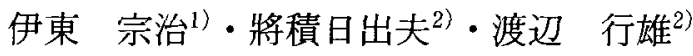 \\ 水越 鉄理 ${ }^{2)} \cdot$ 神田 憲一3) $\cdot$ 大村 明彦()
}

\section{Relationship of ENG Recording Date and ENG Findings}

\author{
Muneharu Ito'), Hideo Shojaku ${ }^{2)}$, Yukio Watanabe ${ }^{2)}$, \\ Kanemasa Mizukoshi ${ }^{2)}$, Kenichi Kanda ${ }^{3)}$, Akihiko Ohmura ${ }^{4)}$ \\ 1) Department of Otolaryngology, Niigata Rousai Hospital \\ 2) Department of Otolaryngology, Toyama Medical and Pharmaceutical University \\ 3) Department of Otolaryngology, Joetsu General Hospital \\ 4) Department of Otolaryngology, Fujiki Hospital
}

Generally, the incidence of nystagmus decreases as the days from the onset of vertigo pass. To evaluate ENG findings accurately, we studied the relationship between the number of patients showing spontaneous and positional nystagmus on ENG and the number of days between onset and the recording day. Also, second recordings were obtained a few months after the first recordings. We reviewed four hundred and forty patients with vertigo and/or disequilibrium investigated by the Department of Otolaryngology of Joetsu General Hospital between 1990 and 1993. The following results were obtained. (1) In patients with peripheral vestibular disorders, the incidence of positional nystagmus within two weeks was higher than that more than two weeks after onset. On second recordings, the incidence decreased to half of that on the first recordings. (2) In patients with central disorders, there was no relationship between the incidence of positional nystagmus and the number of days after onset. We concluded that ENG recording should be carried out as early as possible following onset, especially in patients with peripheral vestibular disorders, and patients should be treated for a few months.

Key words: ENG, spontaneous nystagmus, positional nystagmus

\section{はじめに}

めまい，平衡障害を訴える患者に対し，現在 ENG 記録を用いた平衡機能検查が広く行われて いる。眼振検查に括壮る異常発現率は，上くに末

\footnotetext{
1) 新潟学㷋病院耳鼻咽喉科

2) 富山医科薬科大学耳鼻咽喉科学教室

3) 上越総合病院耳鼻咽喉科

4) 藤木病院耳鼻咽喉科

新専門会員
}

梢性めまいに関しては，めまい発作発症日から遠 くなるにつれ低くなり，検査を施行する時期につ いては可及的すみやかであるべきであるが，実際 はさまざまな制約から日常臨床上の検查施行の時 期についてはばらつきがみられる。したがって, めまい発症からの期間によりどの程度眼振所見が 変化するのかについては診断学的に興味深いが, これまでそれに関する報告は少ない。そこで ENG を用いた初回検査でのめまい発症からの期 
表 1 初回 ENG での異常発現率（末梢性障害）

\begin{tabular}{|c|c|c|c|}
\hline 発症日と検查日の間隔 & 自発眼振 & 頭位眼振 & 温度眼尉 \\
\hline $\begin{array}{lr}7 \text { 日以内 } & (n=75) \\
8 \sim 14 \text { 日以内 } & (n=58) \\
15 \text { 日以降 } & (n=125)\end{array}$ & $\begin{array}{l}38(51 x) \\
31(53 x) \\
62(51 x)\end{array}$ & $\left.\begin{array}{l}68(91 x) \\
47(81 \not) \\
71(57 x)\end{array}\right|^{*} \mid *$ & $\begin{array}{l}43(58 x) \\
29(50 \%) \\
57(46 \%)\end{array}$ \\
\hline$(n=258)$ & $131(51 \%)$ & $186(728)$ & $129(50 \%)$ \\
\hline
\end{tabular}

$*: P<0.01$

間による眼振所見の違いと，また経過観察におけ る再検查時の眼振所見の推移について検討したの で報告する。

\section{対象と方法}

1990年 1 月より1993年12月までの 4 年間に上越 総合病院耳鼻咽倨科を受診しためまい症例の中 で，平衡機能検査を施行した 440 症例（男性 145 名, 女性295名）中, 未梢性障害258症例, 中枢性 障害74症例を対象とした。疾患の診断は日本平衡 神経科学会の診断基準案1) 飞従った。ただし, 中 权性疾患を疑わせる症状や所見がなく, 内耳性難 聴や温度眼振反応の低下，内耳由来と考兄られる 眼振を認める場合は耳性めまいとし，メニエール 病 (24例)，めまい伴亏突発性難聴（16例），良 性発作性頭位めまい症 (59例) と耳性めまい(159 例）を末梢性障害とした。また病巣診断が明らか な梗塞, 出血などの脳血管障害 (72例) や小脳橋 角部腫瘍（2 例）を中枢性障害とした。

ENG 記録による平衡機能検査は初診日以降の 予約検查として，閉眼（暗算負荷）にて行った。 尚, 初診時には簡易平衡機能検查を行い, 頭位眼 振はフレンツェル眼鏡下座位にて観察した。

めまい発作の発症日から ENG 記録による平衡 機能検查を施行した日までの間隔日数を調へ，末 梢性障害と中权性障害の平衡機能検查に批ける異 常発現率を間隔日数別で比較検討した。また初回 検查から $2 \sim 3$ 力月後に ENG 記録に上る再検査 施行した症例（末梢性障害69症例，中枢性障害24 症例）に関しては初回検查と再検査の結果を比較 した。統計学的処理には wilcoxon 検定とカイ二 乗検定を用いた。

結果

（1）末梢性障害例に括ける初回 ENG での異常 発現率（表 1 )
表 2 発症 2 週間以内の末梢障害例の初回 ENG 頭位眼振と発症日からの間隔 $(n=133)$

\begin{tabular}{|c|c|c|}
\hline \multicolumn{2}{|c|}{ 頭位眼振 } & 発症とE NGの間隔 \\
\hline $\begin{array}{l}\text { あり } \\
\text { なし }\end{array}$ & $\begin{array}{l}\mathrm{n}=115(86 \%) \\
\mathrm{n}=18(14 \%)\end{array}$ & $\begin{array}{l}6.9 \pm 3.3 \text { (日)* } \\
8.7 \pm 2.2 \text { (日)* }\end{array}$ \\
\hline
\end{tabular}

発症から検查施行した日までの期間により7日 以内，8 日から14日以内，15日以降の 3 群に分け ると, 3 群とも自発眼振と温度眼振の異常発現率 は50\%前後で明らかな差はみられなかった。頭位 眼振に関しては，7 日以内に検査施行した75症例 では68症例 $(91 \%) ， 8$ 日から14日以内の58症例 では47症例 $(81 \%)$ と高率にみられ，15日以降の 125 症例では71症例（57\%）とめまい発作からの 期間が長くなると低下がみられた。

さらに15日以降の症例では発症日が曖昧となる 例が多くなるため，14日以内の全症例133例に括 いて頭位眼振の有無での間隔について検討した。 眼振ありおよび眼振なしの平均間隔はそれぞれ 6.9日と8.7日で差を認めた（表 2 ）。

（2）末梢障害例に括汁る ENG での異常発現率 の推移（表 3 ）

初回検査がめまい発作から 7 日以内では，自発 眼振 $54 \%$ ，頭位眼振 $100 \%$ にられたものが，再 検時それぞれ $20 \% ， 51 \%$ と著明に低下した。8日 から14日以内の検查でも同じ結果だった。

（3）末梢障害例に和ける初診時のフレンツェル 眼鏡下眼振と初回 ENG 所見の関連（表 4）

めまい発作から 7 日以内の初䛦では，64症例中 38症例 (59\%) に眼振がみられたが，その内初回 ENG で31症例 $(82 \%)$ に眼振がみられ，7症例 
表 3 ENG 再検例飞未使る異常発現率の推移（末梢性障害69例）

\begin{tabular}{|c|c|c|c|c|}
\hline \multirow{2}{*}{ ENG } & \multicolumn{2}{|c|}{ 初回検查 7 日以内 $(n=41)$} & \multicolumn{2}{|c|}{ 初回検查 8～14日 $(\mathrm{n}=28)$} \\
\hline & 初回 & 再検時 & 初回 & 再検時 \\
\hline $\begin{array}{l}\text { 自発眼振 } \\
\text { 頭位眼振 }\end{array}$ & $\begin{array}{l}22(54 \%) \rightarrow \\
41(100 \%) \rightarrow\end{array}$ & $\begin{array}{r}8(20 \%) \\
21(51 \%)\end{array}$ & $\begin{array}{l}15(54 \%) \rightarrow \\
28(100 \%) \rightarrow\end{array}$ & $\begin{array}{r}6(21 \%) \\
13(47 \%)\end{array}$ \\
\hline
\end{tabular}

表 4 発症 1 週間以内の初診時に眼振を認めた末 梢性障害の初診と初回 ENG の間隔（n= 38)

\begin{tabular}{|c|c|c|}
\hline ENG & & 初診とENGの間隔 \\
\hline $\begin{array}{l}\text { 眼振あり } \\
\text { 眼振なし }\end{array}$ & $\begin{array}{l}n=31(82 \%) \\
n=7(18 \%)\end{array}$ & $\begin{array}{r}4.9 \pm 4.2 \text { (日)* } \\
10.7 \pm 3.1 \text { (日) }\end{array}$ \\
\hline
\end{tabular}

$*: P<0.01$

表 5 初回 ENG での異常発現率（中枢性障害）

\begin{tabular}{lrllll}
\hline 発症日と検查日の期間 & 自発眼振 & 頭位眼振 & ETT & OKN \\
\hline 14日以内 & $(n=19)$ & $13(68 \%)$ & $16(84 \%)$ & $12(63 \%)$ & $13(68 \%)$ \\
15 日以降 & $(n=47)$ & $31(66 \%)$ & $39(83 \%)$ & $31(66 \%)$ & $32(68 \%)$ \\
\hline
\end{tabular}

表 6 ENG 再検例に括ける異常発現率の推移（初回検查14日以内）

\begin{tabular}{|c|c|c|c|c|}
\hline & \multicolumn{2}{|c|}{ 自発眼振 } & \multicolumn{2}{|c|}{ 頍位眼振 } \\
\hline & 初回 & 再険時 & 初回 & 再検時 \\
\hline $\begin{array}{l}\text { 末梢性 }(n=69) \\
\text { 中枢性 }(n=24)\end{array}$ & $\begin{array}{l}37(548) \rightarrow \\
18(75 x) \rightarrow\end{array}$ & $\begin{array}{l}14(20 x) * \\
14(588) *\end{array}$ & $69(100 x) \rightarrow$ & $34(49 x) * *$ \\
\hline & & & $*: P<0.01 \quad *$ & 0001 \\
\hline
\end{tabular}

（18\%）では眼振がみられなかった。初回 ENG での眼振の有無に上り，初診と ENG の間隔日数 を比較すると, 眼振ありでの平均 4.9 日に対し, 眼振なしでは平均 10.7 日と間隔が長かった。

（4）末梢性障害と中枢性障害の比較

末梢性障害で異常発現率に差がみられた，発症 から検查施行した日までの期間が14日以内と15日 以降に分けて, 中枢性障害の異常発現率を比較し た（表 5)。中权性障害では，自発眼振，頭位眼 振，ETT，OKNいずれも14日以内と15日以降に 異常発現率に差はみられなかった。
また末梢性障害で初回検査が 2 週間以内に行わ れた69症例では, 再検查時自発眼振, 頭位眼振之 もに半数以下に減少がみられたのに対し，中枢性 障害の 24 症例では, 再検査時の自発眼振, 頭位眼 振の減少は軽度で, 末梢性障害とは差がみられた (表 6 )。

考察

（1）平衡機能検査の施行時期について

めまい症例に対する平衡機能険查は，可及的早 期に行らべきであるといらことは周知の事実であ る。しかし日常業務上検査対応帮約があり，ま 
た患者の都合などから検査までの期間が長くなる こともある。そこで検査データを評価する際は, 発症からの期間を考慮する必要性が生じてくる。

a . 自発眼振

今回私共は, 発症から初診日までに $1-2$ 週間 経過している症例もあるため, 発症日から初回 ENG 検查日までの期間で検討した。その結果, 末梢性障害, 中枢性障害ともに自発眼振の出現率 に関しては発症から 2 週間前後で差はみられなか った。小林ら2）も，ENG 記録によるめむい、平 衡障害例1260例の自発眼振の出現率は初診日から 2 週間以内であれば著しい低下はないと報告して いる。しかしながら，大西ら゙)はとくに内耳障害 例に打いて, 自発眼振の眼振頻度执よび眼振緩徐 相速度は明らかに日数経過とともに減少を来すと 報告して拉り，内耳障害ではできるだけ早期に検 查を行う必要があると考觉られた。

b. 頭位眼振

自発眼振と異なり，末梢性障害に扣いては初回 ENG での頭位眼振の出現率は発症から 7 日以内 施行時 $91 \% ， 8$ 日から 14 日以内 $81 \% ， 15$ 日以降 57 \%と発症からの期間が長くなると低下がみられた （表 1)。さらに14日以内の症例に㧧いても，頭位 眼振ありが眼振なしょりも発症からの期間が短い といら結果が得られた（表 2)。一方, 初診時フ レンッェル眼鏡下眼振がみられた 38 症例中, ENG で眼振がみられなかった 7 例は, 初診と ENG の間隔が平均 10.7 日と眼振がみられた 31 例 の平均4.9日に比べて日数を経ていた（表 4）。 山口4）は，急性一側性迷路障害例31例に対し，フ レンッェル眼鏡下および ENG 記録による頭位眼 振検査を頻回に繰り返し, 発作後 1 週間以内では 方向交代下向性または患側向き方向固定性頭位眼 振が73.5\%, 第 2 週以降では健側向き方向固定性 または方向交代上向性頭位眼振が54.0\% と眼振方 向の変化がみられ, 眼振消失は 7 日目以降であっ たと報告している。したがって頭位眼振について は,できれば発症から 1 週間以内, 少なくとも2 週間以内に検查することが必要と考えられた。

c. そとの他の刺激検査

末梢性障害に扣いても温度眼振の異常検出率 は, 発症から 2 週間以降の検査でも低下屾あまり なく（表 5 ），また中枢性障害に和けるETTや OKN についても同様で（表 6 ），とくに2 週間
以内の検査を考慮しなくてもよいと考えられた。

（2）平衡機能検査に上る経過観察について

末梢性・中枢性障害々もに自発, 注視, 頭位眼 振検査までで，80〜 90\%に異常所見が発現し， ETT, 温度眼振を加えると $95 \%$ 以上の高率で異 常を摘発することがでさる5)。これらの検査は末 梢性・中枢性障害の鑑別上必要であるが, 症状経 過や治療効果をみる上でも重要である。そこで私 共は，日常猃療上は他覚的評価としてフレンッェ ル眼鏡下自発, 頭位眼振検查を主体に経過観察 し，症状や初回の ENG Kよる娭査所見が軽度な ものを除き，適宜 ENG に上る再検查を行ってい る。その結果, 発症 $2 \sim 3$ 力月後の再検査時, 末 梢性障害でも，頭位眼振が約 $50 \%$ にみれてい た。したがって，一般に保存治療に括ける観察期 間の限界とされる ${ }^{6)} 3$ 力月間程度の保存治療が必 要であることが示唆された。一方, 中枢性障害に 扣いては再検査時の自発, 頭位眼振出現率はあま り低下せず，明らかに末梢性障害とは異なってい、 た。したがって眼振が継続してみられる場合には 中枢性障害も念頭に置いて経過を追う必要がある と考兄られた。

\section{まとめ}

末梢性障害と中枢性障害の平衡機能検查に括河 る異常発現率を，めまい発作の発症日から検査ま での間隔日数別で比較検討した。また初回検査か ら $2 \sim 3$ 力月後の再検査の結果を比較した。末梢 性障害では頭位眼振の出現率はめまい発症から 2 週間以内で高く，再検査時には半減した。中枢性 障害ではめまい発症から2 週間以内と以降で眼振 の出現率に差はなく, 再検查時にも眼振が継続す る症例が多かった。その結果，とくに末梢性障害 では発症から少なくとも2 週間以内に検査するこ とが必要であると考えられた。

\section{文 献}

1 ） 1987年めまいの診断基準化委員会答申書 : め まいの診断基準化のための資料. Equilibrium Res 47: 245-273, 1988

2 ) 小林 謙, 大西正樹, 八木聡明, 他 : ENG 検查日の違いによる眼振の变化について一第 一報 眼振出現率からの検討一。耳鼻臨床 74: 2625-2629, 1981

3 ) 大西正樹, 八木聡明, 小林 謙, 他 : ENG 検查日の違いによる眼振の変化について一第 
二報 眼振頻度执よび緩徐相速度からの検討 一。耳鼻臨床 76: 2077-2081, 1983

4 ) 山口直弘：めまいの経過に伴う眼振所見の変 化. 日耳鼻 75: 937-950, 1972

5 ）渡辺行雄, 水越鉄理, 伊藤享子 : 眼振検査所 見からみためまい.平衡障害の診断. 耳鼻臨 床 76: 3153-3157, 1983
6) 二木 隆 : メニエール病の治療効果判定につ いて. Equilibrium Res 46: 238-248, 1987 $\left(\begin{array}{l}\text { 原稿到着 : 平成 } 8 \text { 年 } 1 \text { 月 } 12 \text { 日 } \\ \text { 別刷請求先 : 伊東宗治 } \\ \text { 干930-01 富山市杉谷 } 2630 \\ \text { 富山医科薬科大学耳鼻咽喉科学教室 }\end{array}\right)$ 